Bryn Mawr College

Scholarship, Research, and Creative Work at Bryn Mawr College

2008

\title{
African Women in the New Diaspora: Transnationalism and the (Re) Creation of Home
}

\author{
Mary J. Osirim \\ Bryn Mawr College, mosirim@brynmawr.edu
}

Let us know how access to this document benefits you.

Follow this and additional works at: http://repository.brynmawr.edu/soc_pubs

Part of the Sociology Commons

\section{Custom Citation}

Osirim, Mary J. "African Women in the New Diaspora: Transnationalism and the (Re) Creation of Home." African and Asian Studies 7 (2008): 367-394.

This paper is posted at Scholarship, Research, and Creative Work at Bryn Mawr College. http://repository.brynmawr.edu/soc_pubs/6

For more information, please contact repository@brynmawr.edu. 


\title{
African Women in the New Diaspora: Transnationalism and the (Re) Creation of Home Mary Johnson Osirim Bryn Mawr College
}

\begin{abstract}
:
During the past 25 years, African immigrants have been arriving in the US in increasing numbers due to the push factors of globalization, wars, civil unrest and natural disasters. Drawing on indepth interviews with African women as immigrants in Greater Boston and Philadelphia, this paper will explore how the intersections of gender, race and class affect their contributions to civil society and business development. This work illustrates how transnational ties, specifically in the form of a new pan-Africanism, lead African immigrants to make significant contributions to community revitalization, particularly in historically African American communities. Although African women immigrants are clearly transnationals, in their civic lives, they differ from their male counterparts in their especially strong commitment to improving the lives of their families and communities on this side of the Atlantic.
\end{abstract}

Keywords: Immigration; Transnationalism; Pan-Africanism; Intersectionality; Race Relations; Entrepreneurship; Civil Society

\section{Introduction: Issues and Objectives}

With the growth in African and Caribbean immigration to the US over the past 25 years, we are witnessing the development of a New African Diaspora. Changes in immigration legislation beginning with the Hart-Cellar Immigration Act of 1965, the Immigration Reform and Control Act of 1986, the Immigration Reform Act of 1990, which included the establishment of the Diversity Lottery among other laws, have made it possible for immigrants to enter the US from Africa, especially during the 1990 s, as well as from other regions in the Global South. ${ }^{1}$ In addition to the changes in US immigration law, the US became an increasingly attractive option for Africans seeking to leave the continent due to the prospects for enhanced socioeconomic mobility and the US's position as a technological leader in the past few decades. From

\footnotetext{
${ }^{1}$ The Hart-Cellar Act opened the US to immigrants from the Global South. The Immigration Reform and Control Act required employers to certify their employees' immigration status. It also granted amnesty to those who were out of status and who could prove they had been living in the US for at least two consecutive years before January 1982. The Diversity Program of the Immigration Act of 1990 was instituted to increase the admission of immigrants from nations that have been underrepresented in the US.
} 
the late 1980 s to the present, political and socio-economic conditions on the African continent have also served as major "push" factors for increased migration to the US. Included among these factors are: the current phase of globalization (and the related consequences of economic crisis and adjustment), political instability and corruption, wars, civil unrest and natural disasters. As a result, some Africans have migrated to the US in an effort to further their education, to escape poverty and to seek asylum. Most have legally entered the US under provisions in immigration law for family reunification, to meet the demand for highly-trained specialists or in the status of refugees, asylum seekers or students. Since the terrorist attacks on September 11, 2001, however, it has become increasingly difficult for Africans to visit or settle-in the US (Boyce Davies 2007). ${ }^{2}$ Throughout the peak years of African migration to the US and beyond, both women and men from a range of educational and occupational backgrounds have participated in the immigration streams.

This article will explore one small segment of this New African Diaspora - African women entrepreneurs and/or leaders of community organizations in two major metropolitan areas - Philadelphia and Boston. Drawing on in-depth interviews with 15 women entrepreneurs and/or leaders of African organizations, this exploratory study will examine how their development of transnational identities is leading to successful efforts in the revitalization of parts of major cities and civil society. This sample is part of a larger, on-going study of African immigrants, whose ties on both sides of the Atlantic are strengthening the development of their businesses and some urban neighborhoods, contributing to development in their "home" nations and reinvigorating civil society in the process. Their activities can perhaps be best seen in these neighborhoods, which served as sites in my study: West Philadelphia, Dorchester and Hyde Park

\footnotetext{
${ }^{2}$ Since the attacks on the World Trade Center and the Pentagon on 9/11/01, in an effort to further secure the US, the State Department has increased the requirements and scrutiny of those applying for visas to travel to or settle in the US, especially for those from Global South nations.
} 
in Boston and Worcester, a city south of Boston. This paper, will not present a comprehensive overview of the operation of their enterprises and their many contributions to the revitalization of commercial areas in these cities, but focuses on the transnational ties and the general contributions that these women are making to the maintenance of communities on both sides of the Atlantic. This work will situate the experiences of these immigrants within the context of the literature in migration studies, interrogate how these migrants define themselves and discuss some of their experiences with race/race relations in the US. In many ways, they have forged a new Pan-African identity. In addition, this paper will discuss the role of intersectionality in their lives - how the factors of race, class and gender affect their professional and personal experiences. While these women are clearly transnationals who are making very valuable contributions to the maintenance of their extended families in their nations of origin, they are especially committed to building and improving life for their families and communities in the US. In fact, when compared to their male counterparts, these women have demonstrated a stronger commitment to building civil society organizations in the US, while their male peers have been more concerned with development in their nations of origin. The roles and responsibilities of these respondents as women and mothers explain in large part their stronger commitments to community building in the US as opposed to their countries of birth. Several of them have (or had) school-aged children who encountered problems in the educational system in the US, and their commitment to the educational and occupational success of their children often led them to start and/or join organizations that could advance their children's achievement. In the absence of extended family ties from home, several women also found that community organizations in the US could assist them in addressing their personal and professional needs as women, particularly when one considers the ways in which race, gender and sometimes class 
intersected in their lives and limited their mobility. Further, for some African women, life in the US afforded them greater freedom from the so-called "traditional" values in their nations of origin, which further limited socio-economic opportunities and their overall empowerment. As women of color, they face many challenges in the Greater Philadelphia and Boston areas, but most of them argue that life has been better for them in the US.

In the next section of the paper I embark on an analysis of those theoretical and empirical perspectives that are most useful in making sense of their lives.

\section{Migration Studies: Mapping a New Terrain of Theoretical and Empirical Perspectives}

Over the past 20 years, the current phase of globalization characterized by the substantial movements of capital, populations and ideas suggests that a new body of theory is needed to account for the experiences of populations of color who have recently migrated to the US or elsewhere. ${ }^{3}$ The assimilation theories of the past are no longer tenable in making sense of the experiences and positions in the social hierarchy that newer, post-1965 immigrant groups encounter in the US. ${ }^{4}$ It is at this point where the field of Migration Studies enters the equation complementing the old field of race and ethnic relations in providing greater breadth and specificity in understanding the experiences of migrants around the world. Migration Studies enables us to acknowledge and accord agency to the global movements of populations involved in multiple sites/stages in the process of immigration. They also provide us with the tools to comprehend how the current phase of globalization presents new "push" and "pull" factors for migrants linked to economic crisis/insecurity, wars and political instability in their home countries. While some of these factors might resemble the reasons why many immigrants came

3 I do believe that conflict theories are still important in understanding the vestiges of colonization that persist for several groups in the US including African Americans, Native Americans, Chicanos, Puerto Ricans and Chinese and Japanese Americans.

${ }^{4}$ In 1965, the Hart-Cellar Immigration Act was passed which opened the US to immigration from the Global South. 
to the US in the past, this phase of globalization facilitates transportation and the spread of technology in ways that make information about, communication with, and travel to, foreign shores easier and to some extent more affordable. Of course, this stage of capitalist development in the North has demands for migrant labor that is both similar to and different from earlier periods (Sassen 1988; Hu-Dehart 2007) ${ }^{5}$.

It is precisely in the field of Migration Studies where we can begin to understand the experiences of New African Diaspora immigrants. African immigrants to the US, as well as those migrating elsewhere, are perhaps best understood through the concept of transnationalism. Transnationals maintain "identities that extend across national borders and involve participation in both their home countries and new societies of settlement" (Swigart 2001: 3). These immigrants engage in "transnational practices" which involve:

multi-stranded social relations along family, economic and political lines that link together migrants' societies of origin and settlement. In this way, migrants are said to build transnational social fields that crosses geographic, cultural and political borders (Basch 2001 as cited in Foner 2001: 9).

These multi-stranded social relations involve African immigrants sending remittances back to relatives in their home countries, which are often the critical means of support for many poor families on the continent and indeed, are major contributors to the economies of these nations. ${ }^{6}$ These remittances are a major source of money for food, education for the young and health care for families in Africa. However, these transnational ties are also maintained by migrants' abilities to frequently visit home, to maintain ties via the telephone and the internet and by sponsoring relatives from abroad (Arthur 2000). Further, Stoller noted in his work that West

\footnotetext{
5 Therefore, the US still has great needs for cheap agricultural labor while at the same time demands for highly skilled professionals.

In some cases, remittances from relatives in the North have been found on occasion to exceed the GDP in some nations in the Global South, such as Bolivia. About a decade ago in Ghana, remittances were found to be a major contributor to the Ghanaian economy.
} 
African traders in New York City maintained strong allegiances with trading cartels and their families in Niger, Mali and other West African states. While earlier European immigrants to the US were also likely to maintain ties to their homelands, I argue that the ties of contemporary immigrants of color are far deeper, stronger and likely to be very current, and therefore of longer duration than the ties of old. This is partly due to the changes in technology and economic development (or the lack thereof) linked to globalization and to the issue of "race" and exclusion in the US, which often leads immigrants of color to maintain close ties to home and to their national identities. As Vickerman observed, "transnationalism, by orienting immigrants back to their homelands, strengthens ethnicity and slows the process of assimilation" (2001: 220). Portes (1996) also discussed the increased importance of transnational communities in the US, especially in relation to immigrant entrepreneurship. In their travels back and forth between their home and host nations, transnationals carry both their cultural and political attitudes in both directions. In the case of African immigrants, they share information, develop contacts and establish trust on both sides of the Atlantic, which contributes to the development of their businesses and other ventures in their host societies, as well as the establishment of enterprises in their home nations. As Stoller (2002) observed for many traders from Francophone West Africa, they maintained strong ties to their communities of origin, which facilitated their access to West African crafts and other goods to sell in the US.

This leads us to the question of how Africans are treated by and respond to the "host" society. What ties do Africans develop on this side of the Atlantic? As opposed to older models of assimilation posited by early US sociologists, Portes and Rumbaut (2001) have developed a new, more complex term known as "segmented assimilation." They define segmented assimilation as a situation "where outcomes vary across immigrant minorities and where rapid 
integration and acceptance into the American mainstream represent just one possible alternative" (Portes and Rumbaut 2001: 45). This theory maintains that assimilation is not a uniform process that all groups experience equally and not a desirable process on the part of all migrants, especially those who see their stay as temporary. Further, segmented assimilation allows us to see the pivotal role that "race" plays in the processes of incorporation in the US. Even if they so desire, not all groups will be able to assimilate. Other possible outcomes in their experiences are remaining part of an immigrant enclave or as also noted by Ogbu becoming part of a minority oppositional culture (Ogbu 1978; Portes and Zhou 1993; Portes and Rumbaut 2001).

Moreover, in this theory and in other contemporary empirical works, race and ethnicity play critical roles in the processes of incorporation as well as in socio-economic mobility for immigrants in the US (Portes and Zhou 1993; Waters 1999; Glick Schiller and Fouron 2001; Stepick et al 2003). In this regard, are first generation African immigrants likely to be viewed as African Americans by mainstream society or as Africans? How might their association with African Americans and/or Caribbean immigrants in major cities affect how they are treated by European Americans and in turn, lead to upward or downward mobility?

Bryce-Laporte (1993) discussed the development of a Pan-African identity among Caribbean immigrants to the US. He argued that much of this Pan-African identity stems from the way that black immigrants "find themselves branded and thus bond along racial, regional or pan-ethnic lines" (1993: 40). This view of Pan-Africanism has relevance for contemporary African immigrants but this analysis demands that we first distinguish between the various forms of Pan-Africanism. First, there was political Pan-Africanism launched at the Pan-African Congress held in Ghana in 1919. Political Pan-Africanism focused on the liberation of all African peoples from oppression, the independence of African states and the unity of all black 
peoples and was spearheaded by many African continental and Diasporic scholars and activists including Nkrumah, DuBois, Garvey and Padmore. Second, during the US Civil Rights Movement and the Black Power Movements from the 1950s through the 1970s, which overlapped the period of the independence movements in many African states, cultural PanAfricanism flourished in the Diaspora as African Americans and Afro-Caribbeans adopted forms of African arts and culture for inclusion in their daily lives. This cultural Pan-Africanism was perhaps most evident in the styles of hair and clothing, musical and dance forms as well as in the "taking of African names" that prevailed among many in the African Diaspora.

Today, a new Pan-Africanism exists among immigrants in this study which is linked to Bryce-Laporte's (1993) earlier research and the work of the African Union. With its establishment in 2001-02, the African Union called for "the unity, solidarity, cohesion and cooperation among the peoples of Africa and the African states" (Boyce Davies and M'Bow 2007:15). In subsequent years, the African Union pushed for unity of all African populations and other specific goals including the creation of a Diaspora Fund for investment and development in Africa and the development of a Diaspora database to facilitate collaboration between those on the continent and those in the Diaspora in science and technology as well as in other areas (Boyce Davies and M'Bow 2007). Thus, the African Union sees a pivotal role to be played by those in the Diaspora for the development of the continent (Reddock 2007).

As demonstrated by their transnational ties, most African migrants around the globe remain dedicated to assisting in the development of their homelands regardless of the magnitude of their efforts. In this sense, these migrants, sometimes united with African American and Caribbean populations in their host societies and Africans on the continent, embody the new Pan-Africanism. This new Pan-Africanism differs from the earlier political and cultural forms 
that flourished during the freedom struggles of black peoples on both sides of the Atlantic. However, as noted by Bryce-Laporte (1993), it is also the experience of racism and to some extent classism that leads some African immigrants, such as those in my study, to bond with other Africans, African Americans and Afro-Caribbeans in order to achieve the access to educational, income and occupational resources that are vital to their mobility in the US. As this study will show, such bonds were mainly evident among African women migrants as opposed to their male peers. This expression of the "new Pan-Africanism", though, is not without conflict. As indicated below, in the competition over resources in the current phase of globalization, relations between African immigrants and others in the Diaspora are sometimes strained.

On the other hand, do most African immigrants experience "favored treatment" in gaining access to resources in the US, as many scholars have observed for first generation Caribbean immigrants, or are they likely to be viewed as African Americans, in keeping with the treatment of second-generation Caribbean immigrants and experience downward mobility (Apraku 1996; Portes and Zhou 1993; Waters 1999). Research by sociologists and others has revealed that African immigrants do not experience the returns to education that are realized by Caribbean immigrants, namely they earn lower salaries than one would expect given their educational attainment (Dodoo 1997; Yesufu 2003).

In addition to the variable of race, gender and class further complicate the lives of women of color and more specifically the lives of African immigrant women. Feminist researchers have noted that migration is a gendered process (Kibria 1994; Purkayastha et al 1997; Yesufu 2003; Boyce Davies 2007; Reddock 2007). Intersectionality plays a critical role in the returns that African women receive for their level of educational attainment. A study in Edmonton, Canada, revealed that they received lower salaries and were more likely to be located in lower-status 
service occupations than other recent immigrant groups (Yesufu 2003). These women also faced discrimination in the labor market since many of them held foreign degrees (earned in their nations of origin), had employers who held stereotypical views of black women and had low levels of social capital in their host societies which resulted in their lack of information about jobs and overall life in Canada (Yesufu 2003). Thus, black women migrants often experience the intersection of gender, race and class in their lives, which affects their life chances and is likely to have an impact on the development of their communities. However, immigrant women of color have also demonstrated their agency in establishing organizations to facilitate their entry/immersion into a community and to shield them from the effects of the larger society (Purkayastha et al 1997). Such organizations often provide support in areas such as domestic abuse previously provided by extended family members at home. By "giving voice" to the experiences of immigrant women of color these groups further empower these women.

Although many African women migrate with their husbands and/or children in an effort to improve their economic well-being, not all African women migrate specifically for material gain. Some women of color leave their home countries in an effort to escape unsatisfying relationships and to increase their autonomy. They hope to gain greater control over their labor, their lives and often those of their children (Boyce Davies 2007). Even when women of color migrate along with their families, life in the host society usually involves some renegotiation of gender roles that often benefits women (Kibria 1994).

While this paper does not intend to answer all of the questions surrounding African women and their position in the broader socio-economic system, it will explore African immigrant women's transnationalism, other notions of identity and their assessment of and experience with race relations. Paradigms that explore transnationalism, segmented assimilation 
and intersectionality appear to be the best starting points for such analyses.

\section{Demographic Background: African Immigrants in the US, Philadelphia and Boston}

While Africans have been migrating to the US since the Hart-Cellar Act of 1965, the New African Diaspora really emerged with the significant increase in African (and Caribbean) migration from the 1980s to the present - a change from about 30,000 African immigrants arriving in the mid-late 1960 s to over 350,000 in the decade of the 90 s. As stated above, this increase is specifically linked to the current phase of globalization which has created the largely economic and political "push" and "pull” factors leading Africans to leave the continent.

In the 1960s and 70s, many Africans came for higher education - to attend university to attain bachelors' or graduate degrees or both. At that time, African governments and some US universities sponsored students to study abroad to develop the human capital believed necessary for development and to lead the newly independent states on the continent. Upon completion of their degrees, some African students returned to the continent while others settled in the US. For many, the decision to return after graduation was based in large part on the economic and political conditions that prevailed in their home countries at the time. ${ }^{7}$ The decision of some Africans to return to their nations of origin or to stay in the US was also conditioned by the type of visa they obtained to study in the US. From the 1980s to the present, economic and political crises, such as the imposition of structural adjustment programs, civil wars, and ethnic and religious conflicts have led many Africans to migrate to the US.

Today, Africans still constitute a very small percentage of the overall number of immigrants who come to the US each year - they are about $6 \%$ of all immigrants. According to the 2000 Census, 881,300 Africans resided in the US, comprising about $3 \%$ of the foreign-born

\footnotetext{
7 Thus, many Nigerian students in the 1970s were encouraged by their families and the Oil Boom to return home after completion of their studies. On the other hand, many Ghanaian students in this period were encouraged by their parents to remain in the US due to the presence of the military government at the time.
} 
population. Today, it is estimated that about one million Africans reside in the US. Half of the African population currently residing in the US arrived between 1990 and 2000. It is important to note, however, that these are official statistics for those who enter from such categories as: refugees, relatives of US citizens/permanent residents and those receiving visas through diversity programs. The total number of Africans who enter the country may exceed these approximately 50,000 legal migrants who have been arriving every year over the past decade. (People's Weekly World).

The largest number of African-born populations in the US comes from West Africa, constituting about $36 \%$ of this population in 2000 , followed by East Africans with $24 \%$, and North Africa with $22 \%$ of the African-born population (www.migrationinformation.org). Among the most significant sending countries in Africa are: Nigeria, Ghana, Ethiopia, Sierra Leone, Egypt, South Africa, Kenya and Liberia. By the end of the 1990's, Nigerians were the largest population of migrants from the region constituting about $17 \%$ of all African immigrants, followed by Ethiopians at about 13\% (Arthur 2000).

African-born populations are somewhat scattered throughout the US, with the greatest concentrations found near large cities and in the northeast. Although Philadelphia has been an understudied area in the literature on immigration, it is becoming an increasingly important location for Africans, ranking among the top 10 metropolitan areas with respect to the percentage of the African-born population. According to the 2000 Census, over $2 \%$ of all African-born populations in the US reside in Greater Philadelphia - about 20,392 persons. ${ }^{8}$ They constitute about 6-7\% of the foreign-born in Philadelphia (Welcoming Center for New Pennsylvanians 2004; www.migrationinformation.org). Migrants from just about every African country reside in

\footnotetext{
${ }^{8}$ Slightly over $11 \%$ of the population in Philadelphia is foreign-born.
} 
the Delaware Valley with the largest number coming from Liberia. Many also come from Nigeria, Ethiopia and Ghana (Swigart 2001; Welcoming Center for New Pennsylvanians 2004). This region has also been an important site for resettlement of refugees from Sierra Leone, Ethiopia, Sudan and Liberia (Swigart 2001).

An African presence can be found in several areas of the city. West Philadelphia has become the most important commercial district for African-owned businesses, with several dotting the Baltimore Avenue corridor. Several other communities are now home to Africans - a small Kenyan population lives in Norristown; the Sudanese tend to concentrate in West or Northeast Philadelphia while Sierra Leoneans, Liberians and Ethiopians tend to live in Southwest Philadelphia. Nigerians and Ghanaians tend to be scattered throughout many parts of the Delaware Valley (Welcoming Center for New Pennsylvanians 2004). The region is also home to at least three African mosques and 11 churches, several of which are located in West Philadelphia. The Greater Philadelphia area has also been an important locale for African community organizations and annual events, such as the Odunde Festival. The Coalition of African Communities (AFRICOM), an umbrella group representing African and Caribbean immigrant organizations, is a model association in the city and nationwide. It facilitates African immigrants' access to many vital city services.

In recent years, Massachusetts and the city of Boston have also witnessed important growth in their African-born populations. In 2005, the foreign-born population in Massachusetts was $14.4 \%$ of the total state population, with Africans constituting the second-fastest growing immigrant group in the state (after immigrants from Latin America). The African immigrant population grew by $26.7 \%$ in the $2000-2005$ period totaling 59,322 in 2005 . Boston also experienced substantial growth in the African population, which now numbers 15,975 and 
constitutes $27.2 \%$ of the foreign-born population in the city (American Community Survey 2006). Boston, like Philadelphia is an understudied area of immigration but yet is also among the top 10 cities in the nation having the largest share of the African-born population, with the former having slightly over 3\% of the total African-born population in the US (Migration Policy Institute 2003). The number of Africans in Boston is quite substantial when one considers that it is a much smaller city than Philadelphia (Boston - approximately 590,763 persons in 2006; compared to about 1.5 million in Philadelphia) and that these numbers are for the city of Boston and not for the Greater Boston area. However, Africans living in Philadelphia encounter a more "black" city than is the case for those in Boston since the black population in the former is $44 \%$ of the urban population versus about $25 \%$ of the Boston population.

While African immigrants live in many areas of the city and their surrounding suburbs, African entrepreneurs in Boston, like those in Philadelphia, are making their presence known in neighborhoods that have historically been home to the African American community: Roxbury, Dorchester and Mattapan. Cape Verdeans, Nigerians and Ethiopians are some of the largest populations of the African-born in Boston, as well as in the Greater Boston area.

Although tensions have been noted between some African Americans and black immigrant populations particularly over access to scarce resources such as employment and education (Waters 1999; Glick Schiller and Fouron 2001; Stepick et al 2003), my study reveals that in many cases, African women have joined with their African American sisters in working for improved life chances for those in their communities. These encounters have not always been without tensions, but my study indicates that such tensions were few compared to the bridge-building that occurred between these groups of women to address community needs.

\section{Research Methodology}


During the summer of 2006, I, along with a few student-research assistants, began interviewing African entrepreneurs and civic leaders in the Greater Philadelphia and Boston areas. Six of the 25 interviews conducted in Phase One of this study were with women. ${ }^{9}$ Phase Two began in the summer of 2007 and included interviews with 10 women in these areas.

Respondents were interviewed using an in-depth interview schedule including about 150 open-ended and fixed-choice questions on such issues as: the personal backgrounds of the respondents and their connections to home; their educational, family and occupational histories; their residential history and reasons for migrating to the US; their identity characteristics; the operation of their firms; the establishment of their organizations and their ethnic celebrations. Interviews lasted about 1.5-2.5 hours and were held in the offices or homes of the respondents.

Snowball sampling was largely used to obtain the names of possible participants in this study. Names of businesses and organizations were also obtained from the books, Extended Lives: The African Immigrant Experience in Philadelphia (Swigart 2001) and Immigrant Philadelphia: From Cobblestone Streets to Korean Soap-Operas (Welcoming Center 2004). Informants from Nigerian communities in Greater Boston provided lists of members of civic organizations and churches and thus, Nigerians are over-sampled in this segment of the study.

The identity of the interviewers can also contribute to bias in the study and thus, it is important to acknowledge who the interviewers are. I, an African American woman, conducted some of the interviews along with advanced undergraduate students, a graduate student and an alumna of Bryn Mawr College. A Haitian American undergraduate student worked with me to interview participants in Boston while an African American alumna, an African American graduate student, and a European American male rising senior and I conducted the interviews in

\footnotetext{
${ }^{9}$ One of the six interviews with women was a group interview and thus only five interviews with individuals from Phase 1 will be considered in this study.
} 
Philadelphia. Our identities might have affected the responses that we received to various questions particularly those involving race, ethnicity and gender. I also have connections to the Nigerian communities in these cities through my husband, who was born in Nigeria.

\section{African Women Entrepreneurs and Civic Leaders - Who are They?}

Of the 15 women who will be considered in this study, eight of them reside in the Greater Boston area and seven in metropolitan Philadelphia. Those women interviewed in the Boston area include women working and/or living in Lowell, Brockton, Cambridge and Worcester as well as in the city of Boston itself. East Cambridge and Brockton are important areas of settlement for Cape Verdeans in Massachusetts, while Worcester and Lowell are former industrial cities. With respect to the Philadelphia area, the majority of the respondents worked in the city of Philadelphia, with one participant each living and/or working in Upper Darby (a suburb immediately adjacent to West Philadelphia) and Paulsboro, NJ. Due largely to the identities of my informants in the Boston area, the interviews there were very clustered with respect to nation of origin of the respondents. Six of the interviewees were born in Nigeria, while one was from Ethiopia and another was a Cape Verdean born in Senegal. The Philadelphia sample contained a much broader distribution of respondents - two from Nigeria and one each from the following nations: Guinea (but raised in Senegal), Sierra Leone, Eritrea, Liberia and Cote d'Ivoire. Like the national statistics, however, Nigerians were most highly represented in this study and overall, most immigrants were from West Africa.

The Boston sample consisted of a younger group of African immigrants than their Philadelphia counterparts. The mean age of respondents in the Greater Boston area was 44, with a median age of 42, compared to an average age of 52 and a median age of 53 in Philadelphia. African immigrants are among the most highly educated migrants to the US with at least 
half of their population holding four-year college degrees (Yetman 1999; Arthur 2000; Swigart 2001). Although they possess somewhat lower levels of educational attainment than their male peers in the larger sample, women in this study were strongly committed to education. Four of the participants in the Philadelphia area attained Bachelor's degrees, with two of these women holding graduate degrees as well. One of these women earned her Bachelor's degree in Nigeria and a Doctorate in Education in the US. Boston area participants generally had higher levels of educational attainment than their Philadelphia peers in this study (which is borne out in the larger city statistics), with six of the women holding Bachelors' degrees. Four of these women pursued graduate studies and three of them earned Masters' degrees. Two Bachelors' and one Master's degree achieved by these Boston-area immigrants were awarded in Nigeria. Generally, all participants in these two major metropolitan areas demonstrated significant dedication to educational pursuits throughout their lives. The owner of an African market in Boston earned her Associate's degree in the US, a seamstress received a three-year certificate in dressmaking in London, an entrepreneur completed a three month computer course in the Boston area, a minister pursued studies in theology as an adult in Lagos and a care worker from Francophone Africa earned her GED (General Equivalency Diploma) ${ }^{10}$ in the US. Women who migrated to the US as adults generally worked in their home countries before leaving. They held a range of gendered-occupations including: teachers, salespersons, seamstresses and secretaries.

Each city's sample contained five women who were community leaders, with three entrepreneurs in Boston and two in Philadelphia. The Boston businesswomen were involved in the following activities: a real estate broker, a Sales Director for Mary Kay Cosmetics and the owner of an African market. The Philadelphia entrepreneurs consisted of a restaurant owner and

\footnotetext{
${ }^{10}$ The General Equivalency Diploma (GED) is achieved after passing a group of five tests in secondary-school level subjects. This diploma is considered the equivalent of a high school diploma in the US.
} 
the owner of a beauty supply shop. In four cases, (three in Boston and one in Philadelphia), the African immigrants were employed as Directors of the major community organization in which they were engaged: the African Family Health Organization in Philadelphia, the Ethiopian Women's Alliance, the African Assistance Center of Greater Lowell and the Association des Caboverdians de Brockton, the latter three in the Boston area. In some cases, although less frequently found among this sample than one would expect to find in their home nations, some of the women were engaged in another line of work along with their major activity. For example, the owner of the beauty supply shop also worked as a seamstress for individual clients and a state administrator in Child Welfare is starting a travel agency.

Why did these women migrate to the US? Although five women initially came to join their husbands in their quest for higher education and/or better employment opportunities, two women came in an effort to escape bad marriages, a finding also noted by Boyce Davies (2007) in her work on Caribbean immigrant women. Most women who joined their husbands also seized the opportunity to advance their education and earned Bachelor's, Master's and a Doctoral Degree in the US. Two women came with their husbands in the diversity lottery, while one entrepreneur was an asylum seeker as a result of the war between Ethiopia and Eritrea. Two current African community leaders, one in Boston and one in Philadelphia, migrated to the US as children - one of these a Cape Verdean from Senegal under provisions for family reunification and the other, a Liberian, who was adopted by an African American family.

These women all migrated to the US in the period of the late 1970s to the beginning of the new millennium with most immigrants coming in the 1980s and 90s. Most of them came to the US when they were in their 20s and early 30s, with the exception of two women who were leaving bad marriages, and arrived in their late 30s and 40s. Two women migrated as minors - 
one came specifically for higher education and another came to join her husband.

Slightly over half of these respondents are currently married—four in Philadelphia and four in Boston (of the latter group, one has filed for an annulment). The intersection of class and gender in the lives of two women noted above led them to leave difficult marital situations in Africa in the hopes of improving their lives in the US. Problems posed by patriarchy, polygyny and so-called "traditional" values in their nations of origin led two women to leave bad relationships. One woman, the leader of The African Family Health Organization, left Senegal after a divorce. It was discovered that she could not have children with her husband and as she noted: "If I stayed there, it would be depressing." She further commented:

I quit this marriage. I had everything.... car, a modern home. I decided that I was not for him. I am not a woman who would have a child with another man for him. I came here, left my job as an administrative assistant. When I was leaving, I emptied my home. When I divorced, to go back to the same country would be embarrassing for me (Interview, community leader, Philadelphia, July 2007).

A Boston seamstress also came to the US after she encountered difficulties with her husband's second wife. She had a daughter in the US who urged her to come over for a while. After a three month visit, the entrepreneur became sick and had to be hospitalized. When she had only a few weeks left on her visitor's visa, her daughter, then a citizen, hired an attorney and applied for permanent residency for her mother. Within six weeks, she was approved and later filed to bring her other children to join her. Within a year, she was able to bring her remaining four children to the US. Her migration and that of her family occurred in the late 1980s.

In addition to the four immigrants in the Philadelphia area who are currently married, two are divorced and one is widowed. With one exception, these women were all married to Africans, generally from their country, although not always from their ethnic group. The one 
exception was a Liberian who migrated as a child, was raised by an African American family and married an African American. The latter woman is divorced.

With respect to Boston, three immigrants are divorced and one has never been married. One of the married entrepreneurs is currently seeking an annulment, after experiencing both physical and psychological abuse from her husband, a Nigerian that she married in the US.

All of the Philadelphia area participants had children. The mean and median number of children they had was three. Given the older ages of these interviewees, most of them had adult children (18 years of age or older) with two exceptions: the Liberian-born woman with a 13 year old son, and the Guinean woman from Senegal, who divorced since she did not have children with her first husband, but who now has a 16 year old biological son in the US.

The mean and median number of children for Boston area participants was also three. Given the younger ages of these businesswomen and community leaders, five of them had at least one child under the age of 18 . One unmarried respondent did not have children.

\section{Transnational Identities: Connections on Both Sides of the Atlantic}

Entrepreneurs and community leaders in this study were clearly transnationals. They had maintained close ties to their kin in their home countries through the sending of remittances, building/purchasing and maintaining homes, making frequent visits, and in some cases, purchasing inputs for their US businesses. On the other hand, most of these African immigrants were leaders of community organizations which were strongly committed to enhancing the quality of life and specifically, providing social services for many of their communities in the US. Unlike their male counterparts in these two metropolitan areas who were largely involved with organizations seeking to foster economic and political development in their nations of origin, these women's gaze was quite firmly fixed on enhancing the quality of life for their 
families and communities in the US. Although they certainly contributed to development on the continent, I would argue that more of their efforts were focused on the well-being of their families and other members of theirs and other African communities in the US.

Building and/or purchasing a home in one's country of origin is one way of maintaining ties to the continent, contributing to the well-being of one's extended family and to development. Six of the seven participants from the Greater Philadelphia area owned homes in their nations of origin. The one exception to this was the entrepreneur from Eritrea, who left her country due to the war with Ethiopia. The younger ages of the Boston participants help explain why only four of the respondents owned homes in their birthplaces. As this sample ages, it is highly likely that more of these women will build homes in Africa. Extended family members generally resided in these homes although in some cases, these and other properties were leased to non-relatives.

Every participant in this study was involved in the sending of remittances to their home countries. Such financial contributions are a key source of support for many extended family members, as well as a major source of revenues for several African states. In many nations, remittances continue to be an important source of foreign exchange. These payments contribute to community and national development and demonstrate an immigrant's dedication to fulfilling responsibilities to family and community, to maintaining ties and earning respect at home.

Entrepreneurs and community leaders in this study largely sent these payments to assist their families in the payment of school fees, medical costs, particularly for elderly relatives and to generally supplement family incomes. Some participants sent remittances on a regular basis, while others sent money in response to requests from family members. In some cases, the women sent remittances every month to their parents. Yearly payments to family members ranged from $\$ 500$ - over $\$ 6000$. Most respondents sent a few thousand dollars per year. There 
is no doubt that these cash payments whether for $\$ 1000$ or for several thousand dollars per year were an important source of support for families and community development on the continent.

In a few cases, women were donating money to their nations of origin to promote development. The case that stood out was a Liberian diplomat who sent over $\$ 10,000$ per year:

I send money to Liberia - for humanitarian and educational assistance. Send money generally for the rebuilding of primary schools, money for the collegiate level and for clothing for women and children. I've been doing this for about 12 years. I also send money periodically, according to requests (Interview, community leader, Philadelphia, July 2007).

Respondents in this study also demonstrated their close ties to their nations of birth through their visits home. The frequency with which interviewees traveled home is one of those variables that is quite gendered. Very few African women immigrants in this study visited their nations of origin as often as every year - in fact only two women, one each from Boston and Philadelphia were found in this category. Male respondents, on the other hand, were much more likely to visit home once a year. In addition to the fact that women's incomes in this study were generally less than their male counterparts, childcare responsibilities and the school calendar made it more difficult for women to visit home on a more regular basis, thus illustrating the critical role that the intersection of gender and class played in their lives. In fact, those women who visited home most often both had grown children. Women from areas that had experienced substantial destabilization due to wars and other political crises were also unlikely to have regular visits home, such as those from Ethiopia, Eritrea, Sierra Leone and Liberia.

In addition to maintaining ties through visits and the sending of remittances, women in this study maintained contact with relatives and close associates abroad which enhanced their businesses. As noted by Portes (1996) for immigrant entrepreneurs, African immigrants share information, develop contacts and establish trust on both sides of the Atlantic, which strengthens 
their businesses and other ventures in sub-Saharan Africa. Further, as noted by Stoller (2002), maintaining strong ties to one's community of origin can facilitate access to goods to sell in the US. This was certainly the case for the owner of the African Market in Boston's Hyde Park, who is playing an important role in urban renewal and whose business has become quite successful:

I own the shopping strip - a commercial and residential strip, which includes my business (and another Nigerian-owned business, that includes Western Union)... Only two businesses in this street are African owned, another is Puerto Rican owned, another is white owned. If I locked this place for one day, people would cry. They know that if they need something, I have it. They can get several services/goods from this shopping area...I have a sister who is helping me in Nigeria. When I go home, she tells me where to get the goods and she carries me around. When I am here, I order the goods through her. I get some food from Nigeria. Cassava flour is shipped to me as well as yam flour, Ijebu gari, etc. (Interview with business owner, Boston, August 2007).

Women in this study, however, did not only establish, build and maintain strong relationships with those in their home nations, but they also established strong ties in the US. When compared with their male peers in this study who led African organizations that were largely concerned with development in their homelands, women's efforts as community leaders were very focused on improving the lives of their families and other African and Diasporic populations on this side of the Atlantic. They accomplished this through their leadership of service-oriented organizations in the Boston and Philadelphia areas as well as by building personal ties with others in the Diaspora. These women not only enhanced their communities in the US, but they also contributed to the revitalization of historically African American neighborhoods, the reinvigoration of civil society and the formation of a new Pan-Africanism.

Before discussing some of the contributions to urban renewal and civil society more broadly, let's consider the relationships that these women established and how they identified themselves in the US. The majority of women in this study stated that most of their friends and 
close associates were Africans, followed closely by African Americans and Afro-Caribbeans. One-third (5) of the women counted European Americans, as well as the other black populations in the US in their circle of close friends. When asked how they would describe their identity, most women (6) discussed this in national terms - they stated that they were Nigerian or Ivoirien, for example. Three of the women described themselves as a hyphenated American - as Nigerian-American, Ethiopian-American or Eritrean-American, while a few others simply stated that they are Africans. It was also interesting to note that three women described themselves as African American. None of the participants described themselves as a member of a particular ethnic group from their nations. Such descriptions of identity are quite distinctive from the ways in which African women (and men) typically describe themselves on the continent where they generally use several variables to indicate the complexities of who they are. As BeokuBetts and Njambi (2005) note in quoting the Nigerian feminist scholar, Ogundipe-Leslie:

Until she went abroad, she had never viewed herself as black or used this language to describe other African women. In her culture of origin, the question of one's identity and representation involved multiple and complex signifiers such as that of age, kinship, clan, ethnicity, class and marital status among other things, but never skin color (Beoku-Betts and Njambi 2005).

While the vast majority of women in this study had not considered the issue of race nor race relations in the US before migrating here, several of the women in this study had encountered discrimination and racism at both the institutional and individual levels. As noted by several scholars (Bryce-Laporte 1993; Vickerman 2001; Portes and Rumbaut 2001), race does play a key role in the social placement and everyday experiences of African immigrants and other members of the African Diaspora. Further, as Yesufu (2003) discovered for African migrant women in Canada, not only their race, but also their gender and class (or perceived class) clearly played a role in the treatment that African women received from the broader 
society. A similar finding is observed for women in this study in their roles as mothers, students, wives and workers:

It was my husband's birthday. I had made reservations for dinner at a local restaurant. Then, a white couple came and stood behind us. The maitre'd went and helped the white couple. I decided the establishment did not need my money and I said this. I didn't play the race card, but it is there (Interview with community leader, Philadelphia July, 2006).

For this respondent, the institutional racism in a suburban Pennsylvania school district led

her to start an organization to protect the rights of her children and those of other black parents:

My daughter was in the $99^{\text {th }}$ percentile. North Penn had a two year accelerated math program in middle school. My daughter came home and cried when she told me what was happening in school. The teachers had to screen (test) the children in order for them to be accepted into an accelerated program. The teacher said that since my daughter wanted to become a medical doctor, she did not need to be tested further. She was then told that she draws so well and she does not need this. I went to look at my daughter's folder with $99^{\text {th }}$ percentile scores. Why was she not screened? The Principal said that he did not want to set my daughter up to fail. He made me sign a form - I was not working then, so I was at the school every day...Due to a racial incident in the North Penn School District, I organized 'Concerned Parents for Equity in Education,' from 1989-1996. Parents had many issues as black parents living in the suburbs. Our children were the only black children in their classes. We would initiate meetings with the superintendent. We would have building administrative meetings each month. Many children were assigned to Special Education classes. Parents would ask me to go with them to their children's classes and to their parents' meetings. (Interview with community leader, Philadelphia, July, 2006).

A woman pastor from Worcester, MA also discusses the discrimination that African immigrants experience from institutions:

There are still pockets of discrimination here and there. Even in the schools, black children are having a lot of difficulties. They're being taught by white teachers and the way they are being taught, such as in Worcester, immigrants from Africa who are new residents, the teachers teach the bare minimum. They have already pre-judged them. They discriminate based on their accents. Yes, going to a 
restaurant, for example, you want a chair that is visible, but they put you in a dark corner. Even in doctor's offices, they want to put others before you, so I had to change doctors. (Interview with community leader, Boston, August 2007).

Another woman from Philadelphia admits that her opinion about race relations changed once she was in the US, given incidents she experienced, such as the following:

Ah well... of course, I had experienced racism when I came to the US. I had a personal experience at St. Joseph's University. I fell victim to racism at St. Joseph's, but I fought with it. My professor gave me a "C" which was racially motivated, but gave my white partner a "B" on an educational research project. He said that he thought that my white project partner did the work. (Interview with community leader, Philadelphia, September 2007).

The discrimination that women entrepreneurs have historically faced in borrowing in their home countries rears its ugly head again in the US, where factors of race and gender intersect in the lives of women of color in trying to obtain bank loans:

In banking, we are trying to buy the new church. We were turned down even in our own bank. We bank with them...it is a major bank. We invited the loan officer to the property that we want to buy. We are buying it below value. (He) said I do not think this is the right building for you. There is no concrete reason why he turned us down. The lawyer recommended another bank. They gave us a loan, the interest is a bit high. They called me five times to take the loan. The interest was too high so we did not take this loan. We have gone to a Vietnamese Bank in Worcester and they gave us the loan. (Interview with community leader, Boston, August, 2007).

Entrepreneurs in this study did not just experience discrimination and racism in their business dealings from European American bankers, but also encountered these issues when dealing with other populations of color, especially those who were viewed as controlling the niche economy in such areas as black hair products. ${ }^{11}$ As noted by a Nigerian-born entrepreneur in the Greater Philadelphia area:

\footnotetext{
${ }^{11}$ In many major cities in the northeastern US, the Korean-born own many beauty supply shops, particularly in African American communities.
} 
In everything you do in life, there are problems. Overcoming them is what is important. This business is not supposed to be a black business. There are more Asian businesses (in this field). Many blacks come here and ask to speak to the owner. This used to be a problem. Because of this, we lose some customers to the Koreans. They think you (we) go to the Koreans, buy from them, and then raise the price. They think the Koreans are going to be cheaper. They come to this store and also think that I am not the owner. Even when we go to trade shows... When the Koreans come, they come with money. The Koreans have their own banks, blacks have difficulty getting loans. Often you cannot compete with the Koreanowned businesses. If you are not strong on this, they will buy you out. Many black businesses have closed... You can't go to the bank and get money and the Koreans have their own institutions. If I go to a bank, when you check the application line for black, they do not want to differentiate you from African Americans (Interview with an entrepreneur, Philadelphia, July 2007).

This beauty supply shop owner pointed to another source of discrimination and tension for some respondents in this sample - their relationships with African Americans. Although many interviewees have close relationships with African Americans and some even identify as African American (although in general, they are likely using this term to mean they are "Africans in America"), some participants in this sample did report discriminatory and/or negative experiences with African Americans. In her work on African immigration to the US, Okome (2005) noted that there is a:

conscious decision of black immigrants to distance themselves from the 'undeserving underclass,' (meaning 'African Americans') without consciously apprehending that they are necessarily part of the underclass. It takes events like the Amadou Diallo shooting by the New York City Police to send the clarion call to most African immigrants that they are part of the discreditable, undeserving underclass (Okome 2005).

The director of a Family Health Organization in Philadelphia generally did not demonstrate the distancing attitude from African Americans that Okome (2005) observed for some African immigrants. She discussed the racism she experienced from one African American co-worker 
and her efforts to forgive her, while her African American supervisor was supportive of the participant in this study:

I worked at Penn for five years as a file clerk. My African American friend trained me - she was the supervisor. The other African American woman (in the office) said she would "blow my head off" (in response to a reprimand that the respondent gave to her in the absence of the boss). I said I wanted to take this woman to lunch, and my boss, my African American friend was not here. I said we needed to protect our sister, the boss who was not there (from any conflicts that would ensue from problems in her department). I told her not to say to me again that 'I am a monkey,' etc. If you don't want me to talk, then please tell me...I hugged the woman before I went home and said 'don't let the devil divide us' ...I begged my boss not to fire her. I made peace with her. (Interview with a community leader, Philadelphia, July 2007).

The owner of the African Market in Boston also has a changed attitude about race relations. As a result of a few negative encounters with African Americans, this entrepreneur more closely resembles the African immigrants that Okome (2005) discussed and tries to distance herself from African Americans, whom she sees as perpetrators of many crimes in the Boston area. In my interview with her, she discussed one of these negative experiences:

When I came a long time ago, at Eggleston Station, someone asked for a ride. I gave the two ladies a ride - they took my money from my pocketbook, they were threatening me and said give me your money. They are asking me for directions. No one was hurt. Since that time, I do not give anyone a ride. They were both African Americans (Interview with an entrepreneur, Boston, August 2007).

Discrimination and other negative encounters with African Americans were not the norm for respondents in this sample and in fact, African women in this study overall had fewer negative experiences with all groups around race than their male counterparts (which is perhaps to be understood given the greater threat that black men supposedly pose in the broader society). However, despite the problems that African women in this study encountered, most of them were quite focused on improving the lives of their families, their communities and the broader society 
in the US. While a few women discussed how they would like to return to their home countries in the near future - say in the next two years or so, all of the Boston respondents and half of the Philadelphia respondents claimed that their "lives had been better here than in their nations of origin." Of course, many factors contribute to this response including greater political and economic stability in the US for many and the opportunity to experience greater material comforts than in their nations of origin. Most women expressed some ambivalence about whether they would like to return home in the long run - decisions that would be based on the economic and political conditions prevailing in their countries of birth, the well-being of their children and their lives at the time of retirement.

\section{Building African Immigrant Communities in the US: Women's Leadership in African Organizations}

As stated above, African immigrants are making important contributions to the rebuilding of urban communities in the US, especially in African American neighborhoods in our major cities. This is very much the case in Boston and in Philadelphia, where businesses such as the African Market in Hyde Park in Boston and Dahlak Restaurant in University City and Germantown in Philadelphia are contributing to urban renewal in parts of these major cities. What has been more salient, however, in this sample of entrepreneurs and civic leaders in these two cities are African women's leadership of community associations that are providing vital social services to Africans and the broader community. In several cases, these relationships are strengthening their bonds with other black Diasporic populations, reaffirming their transnational identities and re-invigorating aspects of urban civil society. This section will highlight the activities of some of these groups and showcase the leadership of African immigrant women.

One of the foremost groups in addressing the problems faced by African immigrants in the Greater Philadelphia area is The Coalition of African Communities (AFRICOM). 
AFRICOM is an important vehicle in facilitating settlement in the area and assists immigrants to access resources such as health care and education. In the process, it also helps forge strong relationships with other Black Diaspora populations, such as Afro Caribbeans/West Indians and African Americans. As such, they make major contributions to building a strong Pan-African, Diasporic community.

AFRICOM is an umbrella organization that brings together African and Caribbean community organizations throughout the Greater Philadelphia area. According to one of the participants in my study and a founding member of the group, AFRICOM's mission is: "to empower the African and Caribbean refugee and immigrant communities by facilitating family access to health and social services with special focus on women, children and the youth; promoting economic development; facilitating resolution of inter and intra-group conflicts; advocating on issues of concern to African communities; and educating the media and the broader public on African cultures and experiences" (http://africom-philly.com and interview with community leader July 2006). In its efforts to make health care accessible to all Africans, AFRICOM encouraged the Philadelphia Health Department to hire a French-Speaking health worker to do outreach in the Francophone African immigrant community. The group also assists immigrants and refugees with immigration issues and refers individuals to appropriate legal counsel. Among the special events sponsored by AFRICOM is an Annual Health Fair, which includes on-site HIV testing and social events, such as "Echoes of Africa" to promote knowledge about the diversity and richness of African cultures to the broader Philadelphia community.

Educational initiatives around immigrant issues, especially focused on developing culturally sensitive curricula are some of AFRICOM's major goals. It is precisely in this area that a Nigerian respondent in my study has been most involved in providing very valuable 
expertise as a founding and current board member of the organization. She has been particularly involved in the West African Refugees Assistance Program, which addresses the issues facing children traumatized by wars, several of whom served as child soldiers on African battlefields. Her experience battling the North Penn School District for her own children in suburban Philadelphia well-equipped her to help organize workshops for teachers in the Philadelphia School District to enable them to work with these children. She also played a focal role in organizing multicultural activities within the school district and establishing group therapy for the children. She has clearly been a major leader in shaping the educational environment for many African immigrant and refugee children.

Another group which was established by a Guinean immigrant in this study was the African Family Health Organization (AFAHO). Like AFRICOM, AFAHO exists to serve and empower African and Caribbean immigrants in order to improve their access to healthcare and social services. It especially aims to address the needs of the underserved immigrant populations in the Greater Philadelphia area, particularly those who have major language, cultural and financial barriers preventing them from accessing mainstream institutions. A participant in my study began this organization and is responsible for all aspects of its operation. She provides vital health outreach services, particularly with reference to HIV/AIDS education, testing and counseling. Her office provides language interpreters in several West and East African languages, as well as in Haitian Kreyol, and publishes its materials in English and French. Under her leadership, the organization also provides employment, immigration, educational referral and health services often working in tandem with AFRICOM on such issues. The Director of this group is perhaps best known for the African Health Fair, a major event each year in Philadelphia which provides on-site medical tests and information for those members of the 
broader Philadelphia community that attend the fair. In this sense, the participant in this study has contributed not only to the health, safety and development most especially of low-income members of the African and Caribbean communities, but is also making a vital contribution to the health and well-being of the broader populace.

An association with a somewhat narrower focus on one national immigrant group is the Adbar Ethiopian Women's Alliance in Cambridge, MA. This group is dedicated to social change and women's rights, with a particular emphasis on the conditions that African women, not just Ethiopian women, face who live in the Greater Boston area. Adbar provides a wide range of services to African immigrant women including: legal assistance with immigration issues, literacy training, orientation and acculturation for new arrivals, assistance in accessing social services, such as health care, and advocacy support for issues of domestic violence, female genital cutting, family unification and mental illness. This organization is especially committed to providing job assistance to women to help them achieve financial independence.

The Adbar Women's Alliance is the oldest Ethiopian Women's Organization in the US. The participant who started this group 14 years ago was determined to create a space where women could "share their stories and come to terms with common problems." From the establishment of this organization, she realized that many African women immigrants face problems of female genital cutting and domestic violence, but often accept the blame for these issues. Thus, in addition to creating an organization to provide assistance for these problems, she also organized support groups and began a newsletter as places where women could discuss the challenges that they faced in their families, their households and in the host society. In this way, the Adbar Women's Alliance resembles the South Asian women's group, SNEHA, which provides the "extended family-type" support that is missing from the daily lives of women of 
color immigrants in the US and assists in their empowerment (Purkayastha et al 1997). The leader of the Adbar Women's Alliance also identified specific needs on the part of African immigrants here and sought to address these needs by linking her efforts and expertise with local funders such as The Boston Women's Fund, the Unitarian Universalist Church and the Cambridge Community Fund.

In an earlier interview that the Director of the Adbar Ethiopian Women's Organization shared with me, she revealed her commitment to addressing the immediate needs of the African community that I think is a major focus of many women's efforts in this study:
After working with a few international relief organizations, I found myself disillusioned by some of the groups; their focus on larger goals that seemed to ignore everyday hardships. Lacking a political motivation (a quality that she sees as divisive), I mentioned that I 'longed to organize in a spiritual way.'

\section{Conclusion}

African women in this study were indeed transnationals who exhibited strong connections to their home and host societies and in the process, contributed to development on the continent and the revitalization of parts of historically African American communities. Through sending remittances and maintaining ties to their nations of origin, these women were important sources of support for the health and well-being of their extended family members and at the same time, these linkages benefited the development of their businesses in the US.

Although these women did experience racism as well as the intersection of race, gender and class in their lives, they also forged relationships with other black populations and in fact, contributed to the development of a new Pan-Africanism. Moreover, these African immigrant women were significantly committed to organizations that addressed the "everyday hardships" of life on this side of the Atlantic, which really distinguished them from their male peers. 
This study makes an important contribution to feminist analyses of transnationalism as a gendered process, a very understudied phenomenon especially with respect to African immigrant women. This work reveals that these women established and/or led organizations which facilitated the settlement of African and Caribbean immigrants in the Philadelphia and Boston areas, lending support to Purkayastha et al's (1997) thesis about the valuable roles that support networks play in the lives of immigrant women of color. Such networks enabled women to navigate the often difficult terrain of educational, employment and health care institutions as workers, mothers and sometimes wives, a social landscape that was more problematic for them as black women immigrants (Yesufu 2003; Boyce Davies 2007). These networks often replaced the roles historically occupied by extended families in one's nation of origin. Groups such as the Adbar Women's Alliance further illustrated the agency and empowerment of African women, who developed support groups to address the problems they encountered with domestic violence, female genital cutting and other issues. Through their many activities, these women are assisting in the rebuilding of the urban social landscape, saving lives and re-creating "home."

\section{Bibliography}

Apraku, Kofi. Outside Looking In: An African Perspective on American Pluralistic Society. Westport, CT: Praeger, 1996.

Arthur, John. Invisible Sojourners: African Immigrant Diaspora in the United States. Westport, CT: Praeger, 2000.

Basch, Linda. "Transnational Social Relations and the Politics of National Identity: An Eastern Caribbean Case Study," in Foner, ed., Islands in the City: West Indian Migration to New York. Berkeley: University of California Press, 2001.

Beoku-Betts, Josephine and Wairimu N. Njambi. “African Feminist Scholars in Women's Studies: Negotiating Spaces of Dislocation and Transformation in the Study of Women. Meridians. Vol. 6, No. 1, 2005. http://muse.jhu/.edu/journals/meridians/v006/6.1_beoku_betts.html

Boyce Davies, Carole. "Caribbean Women, Domestic Labor and the Politics of 
Transnational Migration," in Harley, ed., Women's Labor in the Global Economy:

Speaking in Multiple Voices. New Brunswick: Rutgers University Press, 2007.

Boyce Davies, Carole. “Towards African Diaspora Citizenship: Politicizing and Existing Global Geography," in McKittrick and Woods, eds., Black Geographies and the Politics of Place. Boston: SouthEnd Press, 2007.

Bryce-Laporte, Roy S. "Voluntary Immigration and Continuing Encounters between Blacks: Post-Quincentenary Challenge." Annals of the American Academy of Political and Social Science, Vol. 530, No. 1, November 1993.

Dodoo, Francis Nii-Amoo. "Assimilation Differences among Africans in America." Social Forces, Vol. 76, No. 2, 1997.

Foner, Nancy. New Immigrants in New York. New York: Columbia University Press, 2001.

Glick Schiller, Nancy and Georges Fouron. Georges Woke Up Laughing: Long-Distance Nationalism and the Search for Home. Durham: Duke University Press, 2001.

Hu-Dehart, Evelyn. "Surviving Globalization: Immigrant Women Workers in Late Capitalist America," in Harley, ed., Women's Labor in the Global Economy: Speaking in Multiple Voices. New Brunswick: Rutgers University Press, 1997.

Kibria, Nazli. "Migration and Vietnamese American Women: Remaking Ethnicity," in Zinn and Dill, eds., Women of Color in US Society. Philadelphia: Temple University Press, 1994.

Ogbu, John. Minority Education and Caste. New York: Academic Press, 1978.

Okome, Mojubaolu. "The Antinomies of Globalization: Causes and Consequences of Contemporary African Immigration to the United States of America," in Vaughn, et al, eds., Globalization and Its Discontents, Ibadan Nigeria; Sefer Academic Press, 2005. http://www.africamigration.com/archive_01m_okome_globalization_02.htm

People's Weekly World: http://www.pww.org/article/view/7085/1/270.

Portes, Alejandro and Min Zhou. "The New Second Generation: Segmented Assimilation and its Variants." Annals of the American Academy of Political and Social Science, Vol. 530, No. 1, November 1993.

Portes, Alejandro. "Global Villagers: The Rise of Transnational Communities." The American Prospect, Vol. 7, No. 25, 1996.

Portes, Alejandro and Ruben Rumbaut. Legacies: The Story of the Immigrant Second Generation. Berkeley: University of California Press, 2001, 
Purkayastha, Bandana, Shyamala Raman and Kshiteeja Bhide. "Empowering Women: SNEHA's Multifaceted Activism," in Shah, ed., Dragon Ladies: Asian American Feminists Breathe Fire. Boston: South End Press, 1997.

Reddock, Rhoda. "Editorial: Diaspora Voices." Feminist Africa, Issue 7. http://www.feministafrica.org/index.php/editorial-6

Sassen, Saskia. The Mobility of Labor and Capital: A Study in International Investment and Labor Flow. New York: Cambridge University Press, 1988.

Stepick, Alex, Guillermo Grenier, Max Castro and Marvin Dunn. This Land is our Land: Immigrants and Power in Miami. Berkeley: University of California Press, 2003.

Stoller, Paul. "West Africans: Trading Places in New York," in Foner, ed., New Immigrants in New York. New York: Columbia University Press, 2001.

- Money Has No Smell: The Africanization of New York City. Chicago: The University of Chicago Press, 2002.

Swigart, Leigh. Extended Lives: The African Immigrant Experience in Philadelphia. Philadelphia: The Balch Institute of Ethnic Studies, 2001.

Vickerman, Milton. "Jamaicans: Balancing Race and Ethnicity," in Foner, ed., New Immigrants in New York. New York: Columbia University Press, 2001.

Waters, Mary. Black Identities: West Indian Immigrant Dreams and American Realities. New York: Russell Sage Foundation, 1999.

Welcoming Center for New Pennsylvanians. Immigrant Philadelphia: From Cobblestone Streets to Korean Soap Operas. Philadelphia: The Welcoming Center for New Pennsylvanians and The Historical Society of Pennsylvania, 2004.

Yesufu, Adenike. "The Gender Dimensions of the Immigrant Experience: The Case of African-Canadian Women in Edmonton," in Tettey and Puplampu, eds., The African Diaspora in Canada: Negotiating Identity and Belonging. Calgary: The University of Calgary Press, 2005.

Yetman, Norman, ed. Majority and Minority: The Dynamics of Race and Ethnicity in American Life. Boston: Allyn and Bacon, 1999. 
